\title{
International Legal Issues of the Arab-Israeli Conflict An Israeli Lawyer's Position
}

\author{
Robbie Sabel *
}

The Jews and Palestinians are entitled to self-determination in the historical area of Palestine. An Arab state, the Kingdom of Jordan, has been established in Eastern Palestine and a Jewish state, Israel, in part of Western Palestine. The status of the intermediate area, known as the West Bank is as yet undetermined. It was part of Palestine which the League of Nations destined for a Jewish national home, since, however, the majority of the population of the West Bank are Palestinian Arabs, who are entitled to a right of self-determination, Israel will have to relinquish its claims to this area. The Palestinians for their part will have to accept the Jewish right of selfdetermination in the state of Israel. Among the issues that will need to be negotiated between the parties are borders, the status of Jerusalem, security arrangements, refugees, settlements and water issues.

\section{Keywords}

Jewish People, Palestinian People, Self-Determination, Palestine, Israel, Jordan, Refugees

\section{Introduction}

International law has played a central role in attempts to solve the Arab-Israel conflict. Both Arab and Jewish societies are based on strict written legal codes and in both

* Visiting Professor of International Law, Hebrew University, Jerusalem. Ph.D (Jerusalem). Member of the Israel Bar. The author's book, Procedure at International Conferences: A Study of the Rules of Procedure at the UN AND AT INTER-Governmental Conferences (2006) was awarded the Certificate of Merit of the American Society of International Law. The author wishes to express his thanks to Ms. Ariella Gild for her invaluable assistance in researching and writing this article and to Ms. Ellen Rosenberg for her cogent editorial comments. The author may be contacted at: msrobbie@mscc.huji.ac.il /Address: 107 Yasmin St., Mevasseret 90805 Israel. 
cultures great respect is given to legal matters. Both parties to the conflict tend to base their narratives, their information campaigns and negotiating positions on international law, on the premise that "legitimacy and lawful authority are key components of political power." 1 Israel is an open pluralistic society so there is no one monolithic Israeli view and all this paper can attempt to do is to present some of the major international law issues from the perspective of one individual Israeli jurist. The paper first deals with the fundamental issues of: the right of self determination and Arab and Jewish nationalism; sovereignty over Palestine and the proposed Jewish national home; the territory allocated for the Jewish national home; the end of the mandate and Israel's declaration of independence; the borders of Israel and the status of the West Bank. The paper then examines some of the following issues in international law: occupation; Israeli settlements in the West Bank; international law as an internal element of Israel law; Arab refugees and the claim to a right of return to Israel; refugee property; the law of the return; the Israeli security fence and Israeli measures against Hamas in the Gaza Strip. The final section presents a vision for peace.

\section{The Right of Self-Determination and the Arabic and Jewish Nationalism}

Among the major international law issues involved in the conflict is the question of the right of self-determination. The author would maintain that international law recognize the right of self-determination of both the Jews and Palestinians. ${ }^{2}$ The constitutive elements of a 'people' have been defined as "a history of independence or self-rule in an identifiable territory, a distinct culture, and a will and capability to regain selfgovernance." 3 The Jews share a distinct identity which includes the Hebrew language, the Jewish religion, a complex legal code, national and religious holidays, common cultural icons, a body of literature, a shared historical narrative and a continuing sense of common destiny and people-hood. The Bible was written in Hebrew and is mostly set in the territory of modern day Israel. The Jews have a history of independence and self rule in the land of Israel going back thousands of years. During the long period of

\footnotetext{
Roger Fisher, Points of Choice: International CRises ANd the Role of LaW 12 (1978).

The right is recognized in both the 1966 International Covenant on Civil and Political Rights ("ICCPR") and International Covenant on Economic, Social and Cultural Rights ("ICESCR").

3 Aureliu Critescu, The Right to Self-Determination, U.N. Doc. E/CN.4/Sub.2/404/Rev.1 U.N. Sales No. E.80.XIV.3 (1980), and Hector Gros Espiell, The Right to Self-Determination, U.N. Doc. E/CN.4/Sub.2/405/Rev.1. U.N. Sales No. E.79.XIV.5 (1980).
} 
time, the territory has been subjugated by various empires but no people, other than the Jewish people, has ever had an independent state in the area. Jewish independence continued till 135 A.D. when the Roman Empire suppressed the Jewish revolt, exiled most of the Jewish population and renamed the area Palestine. 4 Throughout the centuries that followed there always remained a Jewish population in Palestine and the majority of the population of Jerusalem has been Jewish for the last 200 years. 5

The latter part of the 19th century and early part of the 20th century saw the growth of both Arab and Jewish nationalism. ${ }^{6}$ Arab nationalism was encouraged by the British Government as part of its campaign against Ottoman Turkey during the First World War.7 After the war, the independent Arab states of Iraq, Lebanon, Syria, Saudi-Arabia and Transjordan (now Jordan) were created. Palestinian nationalism, as a distinct aspect of Arab nationalism developed later; at first the Palestinian Arabs regarded themselves as part of Southern Syria. ${ }^{8}$ Although there were some manifestations of Palestinian nationalism at the beginning of the twentieth century, Palestinian nationalism fully formed after 1948 and further developed after 1967. The Palestinian Arabs are, however, nowadays universally accepted as a people entitled to the right of self-determination.

Zionism, that is, the Jewish national movement, sought to rebuild the Jewish national home within Palestine which at the time was a neglected corner of the Ottoman Empire. ${ }^{9}$ Large scale Jewish immigration to Palestine began in the 1880's. The Jews settled mostly on purchased wasteland, sand-dunes and malarial marshes.10 Between 1919 and 1939, about 360,000 Jewish people immigrated. In addition, over 50,000 Arabs immigrated to Palestine from nearby Arab states, attracted by the improving agricultural conditions and growing job opportunities, mostly created by Jewish

4 The area has been alternately known as 'Canaan,' 'Judea,' 'The Land of Israel,' 'Israel,' 'Eretz Yisrael,' and 'The Holy Land.' After suppressing the Jewish revolt of 135 A.D., the Romans renamed the area as 'Palestine' after the previous coastal inhabitants the Philistines (who bear no relation to the modern day Palestinians.) See BENNY MORRIS, 1948: A History of the First ARAB-IsRaeli War 1 (2008).

5 Israel Central Bureau of Statistics Jerusalem's Population, available at http://www.jewishvirtual library.org/jsource/ History/jerupop.html (last visited on Aug 15, 2010), recited at J. OESTERREICHER \& A. SinAI, (EDS), JERUSALEM 1 (1974).

6 John Norton Moore (ED.), I THe ARAB IsRaEli Conflict 6 (1974).

7 In 1915, the British High Commissioner, in Egypt, Sir Henry McMahon promised Hussein the Sharif of Mecca to support Arab independence in the areas that would be liberated from the Ottomans, with certain areas being excluded. There is controversy over whether Palestine was part of the excluded area. The British Government's position has been stated as "The whole of Palestine west of the Jordan was thus excluded from Sir. Henry McMaho's pledge." See The British White Paper (June, 1922), available at http://avalon.law.yale.edu/20th_century/ brwh1922.asp (last visited on Aug. 15, 2010). McMahon himself has confirmed that he intended to exclude Palestine from the pledge (Letter from Henry McMahon to the Times of London, July 23, 1937) quoted in JuLIUS STONE, IsRael and PALEstine: AsSAUlt ON THE LAW OF NATions 146 (1981).

8 STONE, supra note 7, at 10 (1981).

9 For a description of how desolate Palestine was at the time, see MARK TwaIN, The INNOCENTS ABROAD (1869).

10 Much of the land now carrying orange groves was sand dunes or swamps and uncultivated when it was bought. See U.K. Secretary of State for the Colonies, Report of The Palestine Royal Commission Ch. IX, (July 1937). 
development of the land.11

\section{Origin and Evolution of the Middle East Conflict}

\section{A. Sovereignty over Palestine and the Proposed Jewish National Home}

The Turkish Ottoman Empire ruled Palestine from the Sixteenth Century until World War I. In its peace treaty with the Allied Powers following the war, Turkey relinquished any claim to Palestine. 12 In accordance with international law, as it was at the beginning of the Twentieth Century, the victorious allies had the right to dispose of territory ceded from the Ottoman Empire. Following an ideological shift away from colonialism and towards recognition of the rights of peoples to self-determination, however, the allies did not annex the territories but rather agreed to administer them according to a mandate to be negotiated with the League of Nations. The Council of the League of Nations, in its 1922 Mandate for Palestine,13 incorporated the principle of establishing a Jewish national home in Palestine, a principle that had been set out in an earlier unilateral British statement of policy known as the 1917 Balfour Declaration.14

The mandate of League of Nations by explicitly calling for the establishment of a Jewish national home in Palestine, 15 recognized the right of the Jewish people to self determination in Palestine.16 The Preamble stated "recognition has thereby been given to the historical connection of the Jewish people with Palestine and to the grounds for reconstituting their national home in that country." [Emphasis added] The operative terms declared that: "[T]he Mandatory shall be responsible for placing the country under such political, administrative and economic conditions as will secure the establishment of the Jewish national home ... and also for safeguarding the civil and religious rights of all the inhabitants of Palestine, irrespective of race and religion.” 17

11 Martin Gilbert, The Routledge Atlas of the Arab-Israeli Conflict 16 (8th ED. 2005).

12 Treaty of Peace between the Allied Powers and Turkey (Aug. 10, 1920) \& Treaty of Lausanne (July 24 1923). See Treaties of Peace 1919-1923, Vol. II, 789-941/959-1022 (Carnegie Endowment for International Peace 1924).

13 Confirmed by the Council of the League of Nations July 24, 1922 See LEAGUE OF Nations Official Journal 1007-1012 (1922).

14 See the Balfour Declaration 1917, available at: http://avalon.law.yale.edu/20th_century/balfour.asp (last visited on Aug. 15, 2010).

15 The British Mandate for Palestine, art. 2, confirmed by the Council of the League of Nations, July 24, 1922. See LEAGUE OF NATIONS OFFicial JoURNAL 1007 (1922).

16 Although the term 'self-determination' was not used and it only became a term of international law after the Second World War.

17 Supra note 15. 
[Emphasis added] The mandate referred to the political rights of the Jewish people, but only to the civil and religious rights of the local Arab population. The background to this distinction was the idea that the Arabs would be exercising their political rights in the new Arab states bordering Palestine while Palestine was to be designated for a future Jewish national home. The mandate document stipulated that: "while ensuring that the rights and position of other sections of the population are not prejudiced, [The British Mandatory Authorities] shall facilitate Jewish immigration under suitable conditions." 18 Notwithstanding the instructions of the League of Nations, the British authorities, under Arab pressure, limited Jewish immigration to Palestine. The British restrictions on Jewish immigration continued even after 1938 while six million European Jews were being murdered in a systematic state-sponsored genocide by Nazi Germany. Ships carrying Jewish refugees were shuttled from port to port as no state was willing to grant them entry and many ships were forced to return to Europe. Notable exceptions were certain Asian states, including China which voluntarily gave asylum to many Jewish refugees. The Arabs by now had some twenty independent states. The realisation that no state was obliged by international law to grant asylum to Jewish refugees and that the Jews had no homeland of their own, other than Palestine, led to widespread international support for the creation of an independent Jewish state in Palestine.

\section{B. The Territory Allocated for the Jewish National Home}

While encouraging the reestablishment of the Jewish national home in Palestine, the League of Nations, taking into account the existing Arab population of Palestine, ordered that the Jewish national home be created only in Western Palestine. This excluded the whole of Palestine East of the River Jordan, comprising two thirds of the original mandated territory of Palestine, from being part of the Jewish national home.19 This area, of Eastern Palestine, at the time called Transjordan, now comprises the independent Arab Hashemite Kingdom of Jordan, most of whose population are Palestinian.

In 1947, principally due to the ongoing tension between Jews and Arabs the British mandate authorities returned their mandate to the UN. Subsequently the UN General Assembly, by a two thirds majority, recommended the partition of Western Palestine

18 The British Mandate, art. 6. The terms of the British Mandate were reconfirmed at the San Francisco Founding Conference of the UN. See Nathan Feinberg The Arab Israel Conflict in International Law in, I THE ARAB-ISRAELI ConfLICT 419 (John MoRTon ED. 1974).

19 Memorandum by the British representative under Article 25 of the Palestine Mandate, approved by the Council of the League of Nations on Sept. 16 1922, reproduced at U.N. DOC. A/70, at 2-7 (Oct. 1946). 
into three entities, a Jewish state, an Arab state and a separate international entity of Jerusalem. Although this 1947 UN Partition Plan20 further portioned Palestine and granted the proposed Jewish state only approximately $17 \%$ of the area of mandatory Palestine, 21 the leaders of the Jewish community in Palestine agreed to the partition plan. 22 The partition plan was, however, strenuously rejected both by the Arab community in Palestine and by the Arab states who opposed the very existence of a Jewish state. ${ }^{23}$ Every Arab state which was a member of the UN voted against the Partition Resolution and the representatives of the Palestinians sent a formal note to the UN rejecting the plan.

\section{The End of the Mandate and Israel's Declaration of Independence}

In 1948, on the termination of the British Mandate, the Jewish community in Palestine, basing itself on the principle of self-determination, declared independence as the State of Israel.24 Almost immediately the armies of Iraq, Lebanon, Syria, Egypt and Tranjordan invaded, openly declaring that they were sending their armies into Palestine to prevent the creation of the proposed Jewish state. 25

The U.S. representative to the UN Security Council, commenting on the Jordanian Arab Region invasion of Palestine, stated "we have here the highest type of evidence of the international violation of the law." 26 The Russian representative to the Security Council, Gromyko, said "what is happening in Palestine can only be described as a military operation organised by a group of states against the Jewish state." 27 As a result of the subsequent war and the Arab invasion 6373 Israelis, nearly 1\% of the Jewish

U.N. GAOR, 2nd Sess., 1947, at 131-151 (The Future Government of Palestine, as referred to "the Partition Resolution").

21 Historic Palestine comprised what is today Jordan (approximately 35,640 square miles), Israel (8,019 square miles), Gaza (139 square miles) and the West Bank (2,263 square miles).

24 See the Israel Declaration of Independence, available at http://www.mfa.gov.il/MFA/Peace\%20 Process/Guide\%20to\%20the\%20Peace\%20Process/Declaration\%20of\%20Establishment\%20of\%20State\%20of\%20Israel (last visited on Aug. 15, 2010). Some Arab writers claimed that Israel was created on Arab owned lands but in fact $70 \%$ of the area in which Israel became independent was government land, nearly $9 \%$ of the land was owned by Jews and about $3 \%$ by Arabs who became citizens of Israel. About 18\% belonged to Arabs who left the country before and after the Arab invasion of Israel. See Moshe Aumann, Land Ownership in Palestine, 1880-1948, in MichaEL CURTIS, ET AL., The Palestinians 29 (1975).

25 See Cable of May 15, 1948 from the Secretary General of the League of Arab States to the Secretary General of the UN, U.N. SCOR, Supp., at 83 (May 1948), U.N. SCOR., 3rd Year, 292 nd mtg. at 3, U.N. Doc S/748, U.N. SCOR., 3rd Year, Supp., at 90 (Apr.1948).

26 U.N. SCOR, No. 72, 302 ${ }^{\text {nd }} \mathrm{mtg}$., at 43 (1948).

27 U.N. SCOR, 309th mtg. (1948). 
population of 650,000 were killed.28

\section{The Borders of Israel}

For the first thirty years of Israel's independence, none of Israel's Arab neighbouring states agreed to recognize Israel or to accept permanent borders. The 1949 Armistice Agreement, signed after the 1948 war,29 delimited Armistice Demarcation Lines, known as the 'Green Line.' The Arab states insisted that the Green Line was not given the status of a permanent border. The armistice agreements state that " $t$ ] he Armistice Demarcation Line is not to be construed in any sense as a political or territorial boundary." 30

In 1979 Israel signed a peace treaty with Egypt which recognised the former Palestine Mandate boundary as the new boundary between Israel and Egypt.31 In 1994 Israel signed a peace treaty with Jordan which also recognised the former Palestine Mandate boundary as the recognised boundary (without prejudice to the status of the West Bank and East Jerusalem). ${ }^{32}$ Israel has not signed a peace treaty with Lebanon but an agreement was reached, under UN auspices, to demarcate the former Palestine Mandate boundary and that serves as the de facto boundary. 33 Israel has not yet entered into formal negotiations with Syria but it is clear that the former mandatory boundary will also play a part in such negotiations. 34 On the basis of these precedents it could be argued that Israel's boundaries are those of Palestine as they existed during the British mandate. This, however, raises the question of the status of the 'West Bank.'

\section{E. The Status of the West Bank}

During the period of the British Mandate the whole of Palestine, west of the River Jordan (also referred to as Jordan River), was designated as the area in which a Jewish national home was to be established. However, in accordance with the UN 1947

See On War-Armed Conflict Israel 1948-1999 (Armed Conflict Events Database), available at http://www.onwar.com/ aced/nation/ink/israel/findex.htm (last visited July 31, 2010).

29 The total area of modern day Israel, within the "1949 Green Line" is approximately 20,000 square km. $(8,000 \mathrm{sq}$. miles).

30 General Armistice Agreement, Egypt-Isr., Feb. 24, 1949, 42 U.N.T.S. 251.

31 See Israel-Egypt Peace Treaty, available at http://www.mfa.gov.il/MFA/Peace\%20Process/Guide\% 20to\%20the\%20 Peace\%20Process/Israel-Egypt\%20Peace\%20Treaty (last visited on Aug. 15, 2010).

32 See IsraelJordan Peace Treaty, available at http://www.mfa.gov.il/MFA/Peace\%20Process/Guide\% 20to\%20the\%20 Peace\%20Process/Israel-Jordan\%20Peace\%20Treaty (last visited on Aug. 15, 2010).

33 See Report of the UN Secretary General on UNIFIL, July 20, 2000, U.N. Doc. S/2000/718 (2000). See also Letter of UN Secretary General to the President of the UN Security Council, July 24, 2000, U.N. Doc. S/2000/731 (2000).

34 Itamar rabinowitch, The Brink of Peace; the Israel-Syrian Negotiations 142 (1998). 
Partition plan, the Eastern part of this area, and the Gaza Strip were to form an independent Arab state. As a result of the 1948 war, most of the area designated for an independent Arab state as well as East Jerusalem, came under Jordanian rule. With the approval of the representatives of the Palestinian Arabs, 35 the area was incorporated into Jordan in 1948, designated as the "West Bank of Jordan" and formally annexed to Jordan in 1950. Amman, and not Jerusalem, was the capital. After 1949, the Green Line served as the demarcation between Israel and the West Bank. Throughout the period of Jordanian Rule, although the other Arab states did not recognize Jordanian sovereignty over the West Bank, there was no Arab initiative at the UN calling for the creation of an independent Palestinian state in the West Bank.

In 1967, war broke out between Israel and the neighbouring states including Egypt, Jordan, and Syria. It was triggered by the imposition of an Egyptian blockade on the Strait of Tiran which closed the Gulf of Aqaba, 36 cutting off Israel's only supply route with Asia. With the result of the war, Israel gained control of the Gaza Strip and the Sinai Peninsula, the Golan Heights, and the West Bank and East Jerusalem.

After the 1967 War, the UN Security Council adopted Resolution 242.37 The Resolution was non-binding, 38 but has subsequently been accepted by all the parties to the conflict, including the Palestinians. The operative provision of the Resolution calls for "the establishment of a just and lasting peace in the Middle East which should include the application of both the following principles: i) withdrawal of Israel armed forces from territories occupied in the recent conflict in 1967; (ii) termination of all claims or states of belligerency and respect for and acknowledgment of the sovereignty, territorial integrity and political independence of every state in the area and their right to live in peace within secure and recognized boundaries free from threats or acts of force." An earlier draft resolution which referred to withdrawal of Israeli forces from 'all territories' and from 'the territories' was not put to the vote 39 and the phrases 'the' and 'all' were omitted from the final text.40 [Emphasis added] The Israeli interpretation of the Resolution is that the secure and recognised borders referred to in the resolution need to be negotiated in good faith between Israel and a future Palestinian state in the context of a peace settlement.

For details on the Jericho conference of Dec. 1, 1948, see MARY Wilson, KING ABdUlLAH, BRITAIN, AND the Making OF JORDAN (1987).

36 Robert R. Bowie, Suez 1956 - International CRises AND the Role of LaW 110 (1974).

37 S.C. Res. 242, U.N. SCOR, 22 nd year (Resolutions and Decisions), at 8-9 (Nov. 22, 1967).

38 It was not adopted under Chapter VII of the UN Charter.

39 See Draft UN Security Council Resolution submitted by India, Mali and Nigeria, U.N. Doc. S/8227 (Nov. 7, 1967).

40 The French version reads "retrait des forces armées israéliennes des territories occupies lors du récent conflit." (The Resolution was originally drafted in English) See Ruth Lapidoth, Israel and the Palestinians: Some Legal Issues, 76 Die Friedens-Warte: J. InT'L PeAce \& ORg. 211 (2001). 


\section{F. Occupation}

The West Bank has not been incorporated into Israel, and therefore those areas of the West Bank not part of the Palestinian Authority, are administered by Israel in accordance with the international rules on administering occupied territory. Though the term has negative connotations, occupation is legal in times of armed conflict. The Security Council in fact has never designated the Israeli occupation as illegal.41 More noticeable is that the International Court of Justice ("ICJ"), in its advisory opinion on the Legal Consequences of the Wall which dealt with the status of the West Bank, refrained from characterizing the Israeli occupation as 'illegal.' 42 Former ICJ President, Rosalyn Higgins stated that "[ $t]$ here is nothing in either the Charter or general international law which leads one to suppose that military occupation pending a peace treaty is illegal." 43

\section{Legal Questions Related to the Middle East Conflict}

\section{A. Israeli Settlements in the West Bank}

The political wisdom of setting up Israeli settlements in the West Bank 44 is a controversial issue. It can well be argued, however, that the Palestinians should have been aware that it is impossible to freeze a situation for over forty years. By refusing to reach a peace agreement they have incurred the inevitable result that the demographics of the area have changed over the years by the natural phenomena of population movement and natural increase.

The legality of such settlements rests on the issue of the interpretation of the 1949 Geneva Convention IV relative to the Protection of Civilian Persons in Time of War (the Convention). If the West Bank is the occupied area of a sovereign hostile state party to the Convention, then indeed the Convention forbids an occupier from transferring its

41 The UN Security Council draft resolution referring to the inadmissibility of 'occupation' (UN Doc. S/8227) was not put to the vote. See R. Lapidoth, UN Security Council 242: An Analysis of its Main Provisions, available at http://www.jcpa.org/ text/resolution242-lapidoth.pdf (last visited on Aug. 15, 2010).

42 However, the Egyptian Judge, Nabil Elaraby, in a separate opinion, characterized the occupation as 'illegal.' See Legal Consequences of the Construction of a Wall in the Occupied Palestinian Territory, Advisory Opinion, 2004 I.C.J. 131 (July 9) (Separate Opinion of Judge Elaraby, §III).

43 Rosalyn Higgins, The Place of International Law in the Settlement of Disputes by the Security Council, 64 AM. J. INT'L L. 1, 8 (1970).

44 During the British mandate, Judea and Samaria was the designation used for the area now known as the West Bank and this is the designation used in Israel. The Jordanian designation of the area as the 'West Bank' is more commonly used internationally. 
population to the occupied territory. 45 However, this area was never recognized as sovereign Jordanian territory and Jordan has subsequently relinquished any claim to sovereignty it might have had.46 A sovereign Palestinian state is not yet in existence. Furthermore, it is not apparent that Israel, by allowing or encouraging citizens to live in the West Bank is 'transferring' them, an action prohibited by the Convention. In fact, some of the settlements rebuilt after 196747 date back to the Turkish and mandatory periods and their Jewish residents fled or were expelled by Jordan in the 1948 war.

The West Bank is likely to become the territory of a future Palestinian state. In this case there will be a border with Israel. Only when there is agreement on such a border, will it be apparent whether a settlement is on either the Israeli or the Palestinian side of the border. Settlements on the Palestinian side will be dismantled by Israel unless they have the permission of the Palestinian state to remain. In the past, Israel dismantled all its settlements in Sinai in the context of a peace agreement in which Sinai was restored to Egypt. In the Gaza strip, Israel unilaterally dismantled its settlements.

\section{B. International Law as an Internal Element of Israel Law}

Israel is a democratic state 48 and international customary law is automatically part of Israeli law. ${ }^{49}$ Israel has a highly independent judiciary and its High Court has the authority to overrule any government ruling which it considers to be a violation of human rights. The High Court can even overrule parliamentary legislation which it considers to be in violation of the law on rights of the individual. Recourse to the High Court is open to the Arab population of the West Bank even though they are not Israeli citizens or residents. 50 The High Court has, in many cases, overruled military or security regulations holding them to be in violation of international law. In Public Committee Against Torture in Israel v. The State of Israel case, the Court, prohibiting the application of physical pressure during the interrogation of terrorist suspects, ruled that:

45 The Fourth Geneva Convention Relative to the Protection of Civilian Persons in Time of War of August 12, 1949, art. 49 , para. 6 .

46 The 1988 Declaration by King Hussein on Relinquishing All Rights to the West Bank in favor of the Palestinians, 27 I.L.M 1637-1645(1988).

47 E.g., Hebron, Gush Etzion, Neve Yaakov, Kalia.

48 Israel is the only State in the area listed by 'Freedom House' as free and democratic. See Freedom House, Freedom in the World 2010, available at http://www.freedomhouse.org/template.cfm?page=505 (last visited on Aug. 15, 2010).

49 See Abd Al Nasser Al Aziz Abd Al Aziz Abd Al Affo Et Al v. Commander of I.D.F. Forces in the West Bank (1988) in HCJ 785/87, available at http://elyon1.court.gov.il/files_eng/87/850/007/Z01/87007850.z01.htm (last visited on Aug. 15, 2010). "According to the consistent judgments of this court," Justice Shamgar maintained that: "[C]ustomary international law is part of the law of the land, subject to any contradictory provision in Israeli legislation."

50 Israel is apparently the only state to have ever allowed foreign nationals under military occupation such access to their Courts. 
The rules pertaining to investigations are important to a democratic state. They reflect its character. An illegal investigation harms the suspect's human dignity. It equally harms society's fabric. This conclusion is in accord with international treaties, to which Israel is a signatory, which prohibit the use of torture, "cruel, inhuman treatment" and 'degrading treatment.' These prohibitions are 'absolute.' 51

Some $80 \%$ of the population of Israel is Jewish, but Israeli society is multi racial and composed of different ethnic groups. The Arab minority has the problems traditionally associated with minorities. However, they enjoy the highest standard of living of any Arabs in the Middle East and actively participate in the Israeli political process. There are Arab Parliamentarians, Arab judges including on the Supreme Court, Arab cabinet ministers, Arab heads of hospital departments, Arab university professors, Arab diplomats in the Foreign Service and very senior Arab police and army officers. 52 The High Court of Justice frequently quotes international law precedents when enforcing anti-discrimination rules; racism and incitement to racism are criminal offences under Israel law. 53

\section{Arab Refugees and the Claim to a Right of Return to Israel}

About 700,000 Arabs was estimated to flee from Israel in 1948.54 In Israel's view, this refugee problem was a result of the unwillingness of the Arabs of Palestine and the Arab states to tolerate the existence of an independent Jewish state beside an independent Palestinian state. Had the Arabs of Palestine and the Arab states refrained from launching a war to destroy the emergent Jewish state, there would have been no 1948 War and no refugees. The refugees who fled their homes in 1948 left due to a combination of evacuation orders from the Arab side, Israeli military attacks, and fear of impending attacks, expulsions and general chaos. 55 Rather than absorbing and repatriating the refugees, the surrounding Arab states who hosted them made a point of perpetuating the refugee problem.

51 Public Committee Against Torture in Israel v.1. The State of Israel 2. The General Security Service, H.C. 5100/94 (HCJ 1999). English translation available at, http://elyon1.court.gov.il/files_eng/94/000/051/a09/94051000.a09.pdf (last visited on Aug. 15, 2010).

52 Except for the Arab Druze population, Arabs do not have to do compulsory army service but can, and do volunteer to serve in the army, notably the Bedouin Arabs.

53 The Israel Penal Law of 1977, § 144A, as amended in 1986 and 1992, providing for a penalty up to five years' imprisonment for a person who incites to racism.

54 Louise W. Holborn, The Palestine Arab Refugee Problem in 1 The ARAB IsRaELI Conflict 664, 670 (John N. MooRe ED. 1974).

55 Benny Morris, For the Record, THE GuARDIAN, Jan. 14, 2004, available at http://www.guardian.co.uk/world/2004/ jan/14/israel (last visited on Aug. 15, 2010). 
A Palestinian "right of return" to Israel is based on a number of legal arguments. One argument is that, in accordance with international human rights instruments, a person has the right "to return to one's country." 56 Another claim is based on the International Covenant on Civil and Political Rights ("ICCPR") which states that: "[N]o one shall be arbitrarily deprived of the right to enter his own country." 57 An additional argument is based on the wording of UN General Assembly Resolution 194 which resolves that "refugees wishing to return to their homes and live at peace with their neighbours should be permitted to do so at the earliest practicable date." 58

A response to these arguments is that that the expressions 'one's country' and 'his own country' are intended to apply to the nationals of a state.59 Palestinian refugees are not and never were nationals of the State of Israel. It is important to note that a large part of the refugees moved from homes in what is present day Israel to other territory in historic Palestine and hence if Palestine was their country, they have remained "in their country." The human rights conventions were intended to apply "to individuals asserting an individual right. There was no intention here to address the claims of masses of people who have been displaced as a by-product of war or by political transfers of territory." 60 The General Assembly Resolution 194 is phrased as a recommendation only and the word 'right' does not appear in its wording. Decisions of the UN General Assembly are not binding; they neither constitute international law, nor become binding rules of international law by repetition.61 Paradoxically, at the time, all the Arab states voted against the General Assembly Resolution 194 as they considered it might imply recognition of Israel's right to exist.

There is a Palestinian demand that Israel open its gates not only to those who were displaced during the 1948 war but to their nearly five million descendants, ninety per cent of whom have never lived in the territory that is now Israel. International law does not recognize descendents of refugees as having refugee status and granting over four million Arab Palestinians entry to Israel would lead to Israel's becoming an additional Arab state.

The Universal Declaration of Human Rights, art. 13(2); the Convention on the Elimination of All Forms of Racial Discrimination, art. 5 (d) (ii).

57 ICCPR, art. 12(4).

58 G.A. Res. 194 (III), $\uparrow 11$ (Dec. 11 1948).

59 G.S. Goodwin-Gill, The Right to Leave, Return and Remain, in The Problem of The Refugees IN Light of Contemporary International LaW Issues 101 (VERA GoWlLAND - DEBBas ED., 1996).

60 See Stig Jagerskiold, The Freedom of Movement, in The InTERnational Bill of Rights 180 (Louis Henkin ED. 1981); Ruth Lapidoth, Some Legal Aspects of the Palestinian Refugee Question, 485 JERUSALEM ViewPoINTS (2002); E. Benvenisti and E. Zamir, Private Claims to Property Rights in the Future Israeli-Palestinian Settlement 89 AM. J. INT'L L. 295, 322 (1995).

61 P. Weil, Towards Relative Normativity in International Law, 77 AM. J. INT' L. L. 413, 417 (1983). 
In accordance with State practice as well as commonsense, the nationals of each subdivided state do not have a right to the other state when territory formerly under imperial sovereignty is divided into two states on an ethnic or religious basis. A noticeable example is the division of the Indian subcontinent into India and Pakistan. Palestinian calls for a right of return to Israel are inherently incompatible with those of a two-state solution. The practical outcome of implementation would be two Arab states - one composed of the West Bank and Gaza, the other in place of Israel.

The Security Council Resolution 242, accepted by both parties to the dispute, does not refer to a "right of return," but rather refers to "a just solution to the refugee problem." There is no mention of a "right of return" in the 1978 Camp David Agreement, the Peace agreements with Egypt and Jordan or the 1993 Oslo Accords with the Palestinian Liberation Organisation.62 If a Palestinian state is created on the West Bank, that state would have the sole discretion whether to allow free entry to all persons of Palestinian origin.

\section{Refugee Property}

Under international law, Palestinians refugees who left property behind in what is now Israel are entitled to compensation for that property and the issue needs to be addressed in the framework of any peace agreement between the sides. The same will be true for any Jewish property in the West Bank which will need to be abandoned when there is a Palestinian state.

As background to the issue of compensation for the property of the Arab refugees, it must be borne in mind that from 1948 to 1949 some 580,000 Jews fled to Israel from Arab countries.63 They were forced to leave their property behind, and in some cases, such as in Iraq, special laws were passed depriving them of all rights to their property. Once absorbed into Israel they no longer regarded themselves as refugees nor are they regarded as such by Israel. These former Jewish refugees, however, are also entitled to the compensation for their property.

\section{E. The Law of Return}

The Israel Law of Return 64 grants every Jew (including non Jewish immediate family members) an automatic right to immigrate to Israel. This applies unless the immigrant

\footnotetext{
62 Declaration of Principles on Interim Self-Government Arrangements of Sept. 13 1993, 32 I.L.M. 1525 (1993).

63 A prominent Palestinian international lawyer wrote recently that: "[T]he Arab world retaliated for their [Jewish] expulsion of the Palestinians by forcibly ejecting their own Jewish population to Palestine." See Victor KatTan, From Coexistence to Conquest, International LaW and the Origins of the ARAB-ISRaeli Conflict 1891-1949, 252 (2009).

64 See MD. Gouldman, ISRAEL Nationality LaW (The Institute for Legislative Research and Comparative Law, 1970).
} 
"is likely to endanger public health or the security of the State," 65 hence it is a right even if the person is incapacitated and will clearly be a financial burden on the State. The rationale for this law is inherited from the bitter history of the Jewish people. A vital credo is that Jews have a State that will always be obliged to provide them with a haven.66 Israel is sometimes criticized for the Law which is characterized as discriminatory since non-Jews wishing to immigrate must go through a regular process of naturalisation. There is, however nothing exceptional about Israel's provision of priority citizenship based on descent or associations. For example, Irish nationality law provides discretion for waiver of the conditions for naturalisation for an applicant of Irish descent or Irish associations. 67 Likewise Italian citizenship law grants citizenship to foreign nationals on the basis of descent from an Italian great-grandparent. 68 German citizenship laws have similar provisions.

\section{F. Israeli Security Fence}

Since the 1920s, some Palestinian groups have sustained a policy of violent attacks specifically targeting civilians. Amnesty International has reported that: "[A]ttacks against civilians by Palestinian armed groups are widespread, systematic and in pursuit of an explicit policy to attack civilians. Therefore, they commit "crimes against humanity under international law." 69

Israel has set up security fences along its borders, including around the Gaza Strip. These fences have proved effective in preventing terrorist bombers from entering Israel. A similar security fence is now under construction along the border between Israel and the West Bank. Although most of the fence runs roughly along the Green Line, some of the route is east of the Line. Israel's position is that the fence is a passive, non lethal and legitimate measure taken in self-defence and the harm caused to the population is proportionate to the prevention of terrorist infiltration into Israel.70 When the Israel

65 The Law of Return 5710-1950, arts. 1 \&2.

66 Shlomo Guberman, The Law of Return- 1950, available at http://www.mfa.gov.il/MFA/MFAArchive/20002009/2001/ 8/The\%20Law\%20of\%20Return-\%201950 (last visited on Aug. 15, 2010).

67 The Irish Public Service Information, Citizens Information: Becoming an Irish Citizen through Naturalisation, available at http://www.citizensinformation.ie/categories/moving-country/irish-citizenship/becoming_an_irish_ citizen_through_naturalisation (last visited on June 5, 2010).

68 Italiamerica, Italian Dual Citizenship Requirements, available at http://www.italiandualcitizenship.com (last visited on June 5, 2010).

69 Amnesty International, Middle East: Israel and the Occupied Territories and the Palestinian Authority: Without distinction - attacks on civilians by Palestinian armed groups, available at http://www.amnesty.org/en/library/info/ MDE02/003/2002 (last visited on July 30, 2010).

70 The ICJ gave an advisory opinion that the route of the fence is illegal as it violates the human rights of the Palestinians and Israel has no right of self defence against acts that do not originate from a foreign State. See Legal 
High Court found the harm caused by the fence to be disproportionate, it ordered the relocation. ${ }^{71}$ Furthermore, Israel has officially informed ICJ that, after an agreement will be reached with the Palestinians on an agreed border, Israel will remove the part of the fence that will be on the Palestinian side of the border.72

\section{G. Israeli Measures against Hamas in the Gaza Strip}

Hamas, which controls the Gaza Strip, is regarded, by the European Union and other states as a terrorist organisation. 73 The official Charter of Hamas calls for the obliteration of Israel. 74 The Hamas have conducted a campaign of firing over eight thousand rockets at Israeli civilian towns and villages, most of the rockets being supplied by Iran. Human Rights Watch reported that: "Palestinian armed groups routinely violate international humanitarian law when using Qassam-type rockets to attack Israel. They are unlawfully launching strikes that either are directed against civilians or are indiscriminate because they are not directed at a specific military objective." 75

In order to protect its towns Israel was obliged to take military action against Hamas terrorists in the Gaza Strip. In addition it has imposed a naval blockade to prevent further shipment of arms and military equipment to Gaza. Such a blockade is permissible under international law. ${ }^{76}$ There is no limitation on the import of purely civilian goods and Israel has no control whatsoever over the border between Egypt and the Gaza Strip, a border completely under the control of the Egyptian authorities.

Consequences of the Construction of A Wall In The Occupied Palestinian Territory, Advisory Opinion 2004 I.C.J. (July 9).

71 E.g., Ahmad Issa Abdullah Yassin v. Government of Israel et al, HCJ 8414/05 (Eng. trans.), available at http://elyon1. court.gov.il/verdictssearch/englishverdictssearch.aspx (last visited on Aug. 15, 2010).

72 The Israel Ministry of Foreign Affairs, The Legal Adviser, available at http://www.icj-cij.org/docket/files/131/ 1579.pdf (last visited on Aug. 15, 2010).

73 Eur. Dec. (Sept. 3 2003), available at http://eur-lex.europa.eu/.LexUriServ/LexUriServ.do?uri=OJ:C:2009:261: 0026:01:EN:HTML (last visited on Aug. 15, 2010).

74 "Initiatives, and so-called peaceful solutions and international conferences, are in contradiction to the principles of the Islamic Resistance Movement," See the Hamas Covenant 1988, art. 13 ("Israel will exist and will continue to exist until Islam will obliterate it, just as it obliterated others before it."); Hamas Covenant 1988, pmbl. \& art. 8 ("Jihad is its path and death for the sake of Allah is the loftiest of its wishes"). Quotations are from a translation of the Hamas Covenant 1988 provided by the Avalon Project of Yale Law School, available at http://avalon.law.yale.edu/ 20th_century/hamas.asp (last visited on Aug. 15, 2010).

75 Human Rights Watch, Indiscriminate Fire: Palestinian Rocket Attacks since the IDF Withdrawal, available at http://www.hrw.org/en/node/10911/section/7 (last visited on Aug. 15, 2010).

76 The San Remo Manual on International Law Applicable to Armed Conflicts at Sea of June 12, 1994, art. 118, available at http://www.icrc.org/IHL.nsf/FULL/560?OpenDocument (last visited on Aug. 15, 2010). 


\section{Conclusion: Vision for Peace}

An Arab state, the Kingdom of Jordan, has been established in what was called historically Eastern Palestine and a Jewish state, Israel, in part of Western Palestine. The sovereignty of the West Bank, the area in between the two states, has not yet been determined. The majority of the population of the West Bank are Palestinian Arabs who are also entitled to a right of self-determination. The West Bank was included by the League of Nations in the area destined for the Jewish national home. However, in an agreement establishing a Palestinian State Israel will be called upon to relinquish any legal claims in the West Bank. The Palestinians for their part will have to accept the Jewish right of self-determination in the State of Israel. There are difficult issues that need negotiations such as they include borders, settlements, the status of Jerusalem, and security arrangements. Israel, Jordan and a future Palestinian State share water resources and suffer from a water shortage and will need to negotiate this issue.

Former Prime Minister Olmert declared that: "I believe that, in the course of negotiations between us, we will find the right way ... two states for two peoples, a peace-seeking Palestinian state, a viable, strong, democratic and terror-free state for the Palestinian people; and the state of Israel, Jewish and democratic, living in security and free from the threat of terrorism, the national home of the Jewish people." 77 Prime Minister Netanyahu also gave his vision of "two free peoples living side by side in this small land, with good neighbourly relations and mutual respect, each with its flag, anthem and government, with neither one threatening its neighbour's security and existence." 78

If the West Bank is to constitute an independent Arab state then, in the original area of Palestine, there will be two Arab states, Jordan and Palestine, constituting some eighty percent of the original territory. They may well decide to reach a federal agreement between them. However, that will be a sovereign decision of the two Arab states.

77 Ehud Olmert, Annapolis Summit (Nov. 27, 2007), available at http://www.mfa.gov.il/MFA/Gover nment/ Speeches+by+Israeli+leaders/2007/Address+by+PM+Olmert+at+the+Annapolis+Conference+27-Nov-2007.htm (last visited on Aug. 15, 2010).

78 Benjamin Netanyahu, Foreign Policy Address at Bar Ilan, in HA'ARETz (June 14, 2009), available at http://www.haaretz.com/ hasen/spages/1092810.html (last visited on Aug. 15, 2010). This address was reiterated in his Washington speech on Sept. 2. 2010, available at http://www.state.gov/secretary/ rm/2010/09/146701.htm (last visited on Aug. 15, 2010). 